\title{
Comment And Response DOCUMENT FOR THE LONG-TERM SURVEILLANCE PLAN FOR THE Collins Ranch Disposal Site, LAKEVIEW, OREGON
}

November 1993 
November 1993

Prepared by

Jacobs Engineering Group Inc.

Albuquerque, New Mexico 


\section{SECTION 1}

Site: Lakeview, Oregon

Date: Feb. 12, 1993

Document: Long-Term Surveillance Plan

Reviewer: U.S. Nuclear Regulatory Commission

Comment: 1

First paragraph of Section 1.1 on page 1-1 and Section 4.3 on page 4-1 state that 736,000 tons of dry tailings were relocated to the disposal site. Assuming a unit weight of about $100 \mathrm{lb} / \mathrm{cu} \mathrm{ft}, 736,000$ tons of tailings have a volume of about 545,000 cu yds. However, paragraph 4 of Section 2.1 on Page 2-1 of the LTSP and the Final Completion Report state that $926,000 \mathrm{cu}$ yds of contaminated materials were relocated to the disposal site. Although there appears to be a discrepancy in these values, it may be that the 926,000 value includes windblown and other contaminated materials while the 736,000 value does not. If this is true, then the volume of contaminated material (excluding tailings) is about $381,00 \mathrm{cu}$ yds. Is this correct or is there an error in either the 926,000 value or the 736,000 value?

\section{SECTION 2}

Response: Page 2-1 By: $\underline{\text { J. Crain }}$

Date: Nov. 23,1993

Both values are correct. Approximately 926,000 cubic yards $(708,000$ cubic meters) of contaminated materials are in the Lakeview (Collins Ranch) disposal cell, including tailings, windblown material, vicinity property soil, building rubble, and contaminated woodchips. About 736,000 tons (667,700 tonnes) of materials encapsulated in the cell are classified as tailings.

Plans for Implementation: The following sentence has been added to Section 2.1:

"Approximately 736,000 tons $(667,700$ tonnes) of these contaminated materials are classified as tailings." 


\section{SECTION 1}

Site: Lakeview, Oregon

Date: Feb. 12, 1993

Document: Long-Term Surveillance Plan

Reviewer: U.S. Nuclear Regulatory Commission

Comment: 2

Fourth paragraph of Section 2.1 on Page 2-1 states that the NRC anticipates concurrence (of the Completion Report and Certification Summary) in November 1992. Currently NRC anticipates concurrence pending receipt of additional information from DOE. The November 1992 date should be updated.

\section{SECTION 2}

Response: Page 2-1

By: M. Gawthrop

Date: Nov. 23,1993

Concur.

Plans for Implementation: The sentence has been changed to read:

"The NRC concurred on the DOE's completion report and certification summary in September 1993." 


\section{SECTION 1}

Site: Lakeview, Oregon Date: Feb. 12,1993

Document: Long-Term Surveillance Plan

Reviewer: U.S. Nuclear Regulatory Commission

Comment: 3

Page 2-4 of Section 2.2 of the guidance document states that the LTSP should identify action levels for initiating corrective action or repair. Contrary to this, the LTSP does not identify those action levels.

\section{SECTION 2}

Response: Page 2-9 $\quad$ By: M. Gawthrop

Date: Nov. 23, 1993

Concur.

Plans for Implementation:

The Lakeview long-term surveillance plan (LTSP) section on corrective action has been changed to include discussions on the qualifications of the inspectors, the annual inspections, and corrective action plans. These additions clarify the process that will identify early signs of disposal cell deterioration.

A decision on whether the action levels for each Uranium Mill Tailings Remedial Action (UMTRA) Project site should be qualitative or quantitative is being made on a programmatic level. If necessary, the Lakeview LTSP will be modified after this decision is made. 


\section{SECTION 1}

Site: Lakeview, Oregon

Date: Feb. 12,1993

Document: Long-Term Surveillance Plan

Reviewer: U.S. Nuclear Regulatory Commission

Comment: 4

Fourth line of second paragraph of Section 2.2.4 on Page 2-5. An open parenthesis should be inserted before $0.5 \mathrm{~m}$.

\section{SECTION 2}

Response: Page 2-5

By: C. Silva

Date: Nov. 23,1993

Concur.

Plans for Implementation: Sections 2.2.2 and 2.2.3 were combined into one section, Section 2.2.2. Therefore, the original Section 2.2.4 is now Section 2.2.3. An open parenthesis has been inserted before $0.5 \mathrm{~m}$. 


\section{SECTION 1}

Site: Lakeview, Oregon Date: Feb. 12,1993

Document: Long-Term Surveillance Plan

Reviewer: U.S. Nuclear Regulatory Commission

Comment: 5

Eighth and ninth lines of second paragraph of Section 2.2.4 on Page 2-5 state that the top slope varies from 2 to 4 percent. Drawing LKV-DS-10-1313 of the Final Completion Report also shows that top slope as being 2-4 percent. However, Figure 2.3 of the LTSP shows the top slope as being 3 percent. Please make the appropriate revisions.

\section{SECTION 2}

Response: Page 2-7

By: J. Crain

Date: Nov. 23,1993

Concur.

Plans for Implementation: Figure 2.3 has been changed to reflect the comment. 


\section{SECTION 1}

Site: Lakeview, Oregon

Date: Feb. 12, 1993

Document: Long-Term Surveillance Plan

Reviewer: U.S. Nuclear Regulatory Commission

Comment: 6

First paragraph on page 2-9 mentions both ditch and ditches. Since there is only one ditch at Lakeview, the singular form should be used.

\section{SECTION 2}

Response: Page 2-5

By: M. Gawthrop

Date: Nov. 23, 1993

Concur.

Plans for Implementation: The word "ditches" has been changed to "ditch." 


\section{SECTION 1}

Site: Lakeview, Oregon

Date: Feb. 12,1993

Document: Long-Term Surveillance Plan

Reviewer: U.S. Nuclear Regulatory Commission

Comment: 7

First paragraph on page 2-10 mentions diversion channels. Since the RAP and the As-Built drawings use the term "drainage ditch" and there is only one ditch, the words "diversion channels" should be changed to "diversion ditch."

\section{SECTION 2}

Response: Page 2-10

By: M. Gawthrop

Date: Nov. 23, 1993

Concur.

Plans for Implementation: The word "ditches" has been changed to "ditch." 


\section{SECTION 1}

Site: Lakeview, Oregon

Document: Long-Term Surveillance Plan

Date: Feb. 12,1993

Reviewer: U.S. Nuclear Regulatory Commission

Comment: 8

Third paragraph on page 2-10 states that all contaminated materials were placed at around their optimum moisture as opposed to wetter than optimum. This statement does not appear to be supported by the information in Section 3 of Appendix $E$ of the Completion Report, which shows that about 50 percent of the contaminated materials were placed wetter than optimum. If the statement cannot be supported, it should be deleted.

\section{SECTION 2}

Response: Page $\underline{2-10}$

Based on data from moisture-density tests taken soon after compaction of a lift of contaminated material, some of the contaminated material was placed at above optimum (wetter) moisture content. The U.S. Department of Energy (DOE) maintains, however, that after pressure equilibration throughout the disposal cell profile, most material will be close to (approximately \pm 2 percent) its optimum moisture content.

Plans for Implementation: The sixth sentence of the third paragraph has been changed to read as follows:

"After pressure equilibration within the disposal cell (generally a few months), all contaminated materials will be near their optimum moisture content, further protecting the groundwater near the disposal site." 


\section{SECTION 1}

Site: Lakeview, Oregon

Date: Feb. 12,1993

Document: Long-Term Surveillance Plan

Reviewer: U.S. Nuclear Regulatory Commission

Comment: 9

Figure 2.3 on page 2-7 shows the rock/filter layers and the radon barrier layer as being $0.3 \mathrm{M}-15 \mathrm{CM}$ thick. This term is confusing in that it appears to mean that the layers vary from 0.3 meter to 15 centimeters. This is not the case, as the layers are 1 -foot 6-inches thick. A more appropriate and understandable notation would be to show layer thicknesses as either 46 centimeters or 0.46 meter.

\section{SECTION 2}

Response: Page 2-7

By: J. Crain

Date: Nov, 23, 1993

Concur.

Plans for Implementation: Figure 2.3 has been changed to show thickness as 0.46 meter. 


\section{SECTION 1}

Site: Lakeview, Oregon

Date: Feb. 12,1993

Document: Long-Term Surveillance Plan

Reviewer: U.S. Nuclear Regulatory Commission

Comment: 10

Third paragraph of Section 3.0 on page 3-1 and second paragraph of Section 3.4 on page 3-2 state that, "All drawings, maps, and photographs will be archived in the permanent Lakeview site files at GJPO (See Attachment 6)." Since Attachment 6 in the LTSP does not contain any of these items, it is not clear whether drawings,

maps, and photographs will be included in the LTSP or just at GJPO. Actually, since Attachment 6 is blank, its not clear exactly what will be included in the Attachment.

\section{SECTION 2}

Response: Page 3-1

By: C. Silva

Date: Nov. 23, 1993

Concur.

Plans for Implementation: The following sentence has been added to the second paragraph:

"An index of the Lakeview permanent site file is provided in Attachment 3." 


\section{SECTION 1}

Site: Lakeview, Oregon

Date: Feb. 12, 1993

Document: Long-Term Surveillance Plan

Reviewer: U.S. Nuclear Regulatory Commission

Comment: 11

Sections 3.1 and 3.2 or page 3-1 state that the disposal site vicinity map and the disposal site topographic map can be found in the permanent site atlas which is maintained in the permanent Lakeview site file. Will the site atlas be included in Attachment 6 of the LTSP?

\section{SECTION 2}

Response: Page 3-2 By: C. Silva Date: Nov. 23, 1993

No. Attachment 3 contains an index of the permanent site file.

Plans for Implementation: The third paragraph in Section 3.2 has been changed to read:

"All Collins Ranch disposal site base maps and periodic disposal site inspection maps will become part of the Lakeview permanent site file (Attachment 3)."

The reference to Attachment 6 in Section 3.2 has been deleted. 


\section{SECTION 1}

Site: Lakeview, Oregon

Date: Feb. 12, 1993

Document: Long-Term Surveillance Plan

Reviewer: U.S. Nuclear Regulatory Commission

Comment:

Third paragraph of Section 3.3 on page 3-2 states that the Lakeview disposal site map is presented in Plate 1. First bullet of Section 3.7.1 on page 3-5 states that the Permanent site surveillance features are shown in Plate 1. The LTSP does not contain a Plate 1.

\section{SECTION 2}

Response: Page Plate 2

By: J. Crain

Date: Nov. 23,1993

Concur. Plate 2 is the Lakeview (Collins Ranch) disposal site final topographic map. It was inadvertently omitted from the LTSP.

Plans for Implementation: Plate 2 has been added to the document. 


\section{SECTION 1}

Site: Lakeview, Oregon

Date: Feb. 12, 1993

Document: Leng-Term Surveillance Plan

Reviewer: U.S. Nuclear Regulatory Commission

Comment: 13

First line of first paragraph of Section 4.1 on Page 4-1 states that two permanent survey monuments have been installed at the disposal site. However, the last sentence of the same paragraph states that there are three survey monuments. (The topographic map in the LTSP also shows three monuments.) Please correct this apparent discrepancy.

\section{SECTION 2}

Response: Page 4-1 By: L. Crain

Date: Nov, 23, 1993

Concur. Three permanent survey monuments are at the Lakeview site; two of the three survey monuments are also used as boundary monuments.

Plans for Implementation: The text has been changed. 


\section{SECTION 1}

Site: Lakeview, Oregon

Date: Nov. 10,1993

Document: Leng-Term Surveillance Plan

Reviewer: U.S. Nuclear Regulatory Commission

Comment: 14

The hydrostratigraphy for the site is adequately discussed and has been previously defined for the site. A similar situation exists for the background water quality. However neither of these discussions fully support the programs that will be derived from them later in this section. The monitored constituents as well as the monitoring frequency should be modified based upon the site-specific characterization work that has been completed.

\section{SECTION 2}

Response: Page 5-4 to 5-8, 5-11 to 5-14 By: K. Monks Date: Nov, 23, 1993

The DOE agrees with the U.S. Nuclear Regulatory Commission's (NRC) comment. Comment response nos. 15 and 16 address NRC concerns regarding the monitored constituents. Comment response no. 18 addresses concerns regarding monitoring frequency.

Plans for Implementation: The monitored constituents and monitoring frequency have been modified in the final Lakeview LTSP. Section 5.1.3 discusses the revised monitored constituents and concentration limits. Section 5.3.1 discusses the revised sampling frequency. 


\section{SECTION 1}

Site: Lakeview, Oregon

Date: Nov. 10,1993

Document: Leng-Term Surveillance Plan

Reviewer: U.S. Nuclear Regulatory Commission

Comment: 15

Table 5.2 indicates that barium, lead, selenium, and silver were not measurable at concentrations above detection limits. However, all of these constituents are defined, in Table 5.3, as long-term monitoring constituents. The likelihood of detecting these constituents at concentrations at or above the MCL's is beyond remote not only because the constituents are not in the tailings fluid, but also because the MCL's are in every case at least five times greater than the detection limit. Barium, lead, selenium, and silver should be deleted from the monitoring program.

\section{SECTION 2}

Response: Page 5-4 to 5-8 By: K. Monks

Date: Nov. 23, 19:13

The DOE agrees with the NRC's comment. Barium, lead, selenium, and silver have been deleted from the long-term monitoring program.

Plans for Implementation: Section 5.1.3 and Table 5.3 were modified to delete barium, lead, selenium, and silver from the long-term monitoring program. 


\section{SECTION 1}

Site: Lakeview, Oregon

Document: Long-Term Surveillance Plan

Date: Nov. 10,1993

Reviewer: U.S. Nuclear Regulatory Commission

Comment: 16

Table 5.3 lists mercury, net gross alpha, and total dissolved solids. All of these constituents should be deleted from the monitoring program. Mercury is not known to be mobile and has not been identified in the groundwater at any mill sites. Gross alpha is accounted for in the measurement of uranium and radium. Total dissolved solids is somewhat redundant when conductivity measurements are made.

\section{SECTION 2}

Response: Page 5-4 to 5-8 By: K. Monks

Date: Nov. 23, 1993

Comment acknowledged.

Mercury has been deleted from the monitoring program.

Gross alpha radium-226 (Ra-226), and radium-228 (Ra-228) have been omitted from the monitoring program. Activities of gross alpha and Ra-226 and Ra-228 were not measured in the tailings pore fluid solution. However, the average activities of these constituents are less than the maximum concentration limits (MCL) and in the same range as background in groundwater samples collected from shallow on-site and downgradient monitor wells. As a result, net gross alpha and Ra-226 and Ra-228 are not considered potential hazardous constituents of concern at the Lakeview (Collins Ranch) disposal site. Because uranium was detected in the tailings pore fluid solution above the MCLs and is expected to be the most mobile radionuclide in solution, monitoring for uranium (instead of net gross alpha and Ra-226 and Ra-228) will ensure that the disposal cell is in compliance.

Conductivity measurements and total dissolved solids (TDS) measurements may not be directly correlated. Furthermore, TDS measurements provide supplemental information, to verify that the sum of cations and anions is accurate, for analytical quality assurance/quality control. As a result, TDS is considered an important indicator parameter and will remain in the long-term monitoring program.

Plans for Implementation: See modifications to Section 5.1.3 and Table 5.3. 


\section{SECTION 1}

Site: Lakeview, Oregon

Document: Long-Term Surveillance Plan

Date: Nov. 10,1993

Reviewer: U.S. Nuclear Regulatory Commission

Comment: 17

The direct monitoring network in Section 5.2.1 consists of 16 wells. It is unclear why four background wells are incorporated into the monitoring program.

Background concentrations at this site assume less importance because higher MCL's define the standards. Due to this, the need to monitor any or all of the background wells should be revisited. The four additional downgradient monitor wells (520 to 523) also seem redundant. The eight point of compliance wells are more than adequate to detect leakage from the cell should it occur. Due to this, the four additional downgradient wells could be deleted from the program.

\section{SECTION 2}

Response: Page 5-8 to 5-10 By: K. Monks

Date: Nov. 23,1993

Comment acknowledged. The direct monitoring network has been reduced from 16 wells to 9 wells [1 background and 8 point of compliance (POC) monitor wells].

Only one of the background monitor wells will be sampled in the long-term monitoring program. This background monitor well $(515)$ is the closest to the upgradient edge (west side) of the disposal cell. Monitoring this background well is needed to detect any regional changes in background water quality over time.

The four additional downgradient monitor wells $(520$ to 523 ) have been deleted from the long-term monitoring program.

Plans for Implementation: Section 5.2.1 has been modified to reriuce the number of background wells sampled from four (wells 513 to 516) to one (vell 515) and to delete the four additional downgradient monitor wells (520 to 523). 


\section{SECTION 1}

Site: Lakeview, Oregen

Date: Nov, 10,1993

Document: Long-Term Surveillance Plan

Reviewer: U.S. Nuclear Requlatory Commission

Comment: 18

Section 5.3.1 discusses the frequency of monitoring. Based upon the projected travel time of tailings fluid, should it leach, it appears that it would be many years before hazardous constituents would reach the point of compliance wells.

Consequently, the semiannual monitoring through 1994 serves no useful purpose and should be modified to annual.

\section{SECTION 2}

Response: Page 5-11 to 5-13 By: K. Monks $\quad$ Date: Nov. 23, 1993

Comment acknowledged. A sampling frequency of once every 5 years is recommended. This recommended sampling frequency is based upon the following information:

The groundwater compliance strategy is hydrogeologic isolation. The disposal cell design was optimized to include a 2-foot $(\mathrm{ft})$ [0.6-meter $(\mathrm{m})]$ thick geochemical/flow barrier liner on the sides and below the tailings. More than $40 \mathrm{ft}(12 \mathrm{~m})$ of natural fine-grained materials separate the base of the disposal cell foundation from the water table.

The time it would take for any potential seepage from the disposal cell to reach the water table has been calculated from tritium analyses. Tritium concentrations were measured at three depths and were compared to the tritium concentration of a nearby surface water sample. The following travel times were estimated: at least 2 years for a $4-\mathrm{ft}(1-\mathrm{m})$ depth, at least 5 to 6 years for a 10-ft $(3-\mathrm{m})$ depth, and at least 30 years for a $30-\mathrm{ft}(9-\mathrm{m})$ depth. Based on these analyses, the assumption of vertical seepage through a porous medium, the projected travel time of the tailings fluid ranges from less than 1 foot per year $\left(\mathrm{ft} / \mathrm{yr}\right.$ ) to $2 \mathrm{ft} / \mathrm{yr}\left[1 \times 10^{-6}\right.$ centimeters per second $(\mathrm{cm} / \mathrm{s})$ to $2 \times 10^{-6} \mathrm{~cm} / \mathrm{s}$ ). The depth to the water table at the POC ranges from 96 to $120 \mathrm{ft}(27$ to $36 \mathrm{~m})$. Based upon the projected travel time, potential seepage from the disposal cell would not reach the water table at the POC for at least 50 years, and more likely for 100 years. 
The average horizontal linear groundwater velocity beneath the disposal site was estimated to range from 10 to $20 \mathrm{ft} / \mathrm{yr}\left(1 \times 10^{-5}\right.$ to $\left.2 \times 10^{-5} \mathrm{~cm} / \mathrm{s}\right)$. If any potential seepage from the disposal cell reached the water table, its lateral movement would take more than 250 years to move 1 mile $(\mathrm{mi})[2$ kilometer $(\mathrm{km})]$ to the closest well.

A statistical analysis was used to compare the water quality of background groundwater upgradient of the disposal site to the water quality at the POC. No statistically significant changes were noted.

Plans for Implementation: Section 5.3.1 has been modified to recommend a sampling frequency of once every 5 years and to provide rationale for this recommendation. 
SECTION 1

Site: Lakeview, Oregen

Document: Leng-Term Surveillance Plan

Reviewer: U.S. Nuclear Regulatory Commission

Comment: 19

The term "9-mil" at the end of the first line on Page 7-2 should be "9-mi."

\section{SECTION 2}

Response: Page 11-1, 11-2

By: M. Gawthrop

Date: Feb. 12,1993

Concur.

Plans for Implementation: Notification of unusual events at the Lakeview (Collins Ranch) disposal site information has been moved to Section 11.2, Unusual Occurrences.

In Section 11.3, the term 9-mil has been changed to read:

"Any earthquake of magnitude 3.0 or greater, within 0.3 degree [about $20 \mathrm{mi}$ $(30 \mathrm{~km})]$ of the site." 


\section{SECTION 1}

Site: Lakeview, Oregen

Date: Feb. 12, 1993

Document: Long-Term Surveillance Plan

Reviewer: U.S. Nuclear Regulatory Commission

Comment: 20

Section 12.0. The Quality Assurance Program Plan should be referenced and a copy of the plan provided to NRC.

\section{SECTION 2}

Response: Page 12-1

Date: Nov. 23, 1993

The Quality Assurance Manual (previously referenced in Section 12.0 as the Quality Assurance Program Plan) was prepared by the DOE Grand Junction Projects Office (GJPO). The NRC can request a copy of the Quality Assurance Manual from the GJPO.

Plans for Implementation: Section 12.0 of the Lakeview LTSP has been modified to refer to the GJPO Quality Assurance Manual, rather than the Quality Assurance Program Plan. 


\section{SECTION 1}

Site: Lakeview, Oregen

Document: Long-Term Surveillance Plan

Date: Feb. 12, 1993

Reviewer: U.S. Nuclear Regulatory Commission

Comment: 21

Fourth bullet on page 6-2 states that along with the NRC, the State of Oregon's Department of Environmental Quality, Land Quality Division, will be notified when an inspection is to be conducted. The NRC is not aware the State of Oregon has a Land Quality Division.

\section{SECTION 2}

Response: Page 6-2

By: M. Gawthrop

Date: Nov. 23, 1993

Comment acknowledged.

Plans for Implementation: The title "Land Quality Division" has been changed to "Land Use Division." 


\section{SECTION 1}

Site: Lakeview, Oregon

Document: Long-Term Surveillance Plan

Reviewer: U.S. Nuclear Regulatory Commission

Comment: 22

Attachment 3 has copies of letters from DOE to two Federal agencies and one State agency requesting that DOE be notified whenever unusual events such as earthquakes, floods, tornados, etc., occur. The: $\theta$ is no indication, however, that the agencies responded to DOE's requests. Since the attachment is titled "Agency Notification Agreements," it is suggested that the written agreements from the agencies be included in Attachment 3.

\section{SECTION 2}

Response: Page Attachment 7

Concur.

Plans for Implementation: The agencies that have not responded will be contacted. When the written agreements are received, they will be added to Attachment 7 , Agency Notification Agreements, and included in the Lakeview permanent site file. 


\section{SECTION 1}

Site: Lakeview, Orfgon

Date: Feb. 12,1993

Document: Long-Term Surveillance Plan

Reviewer: U.S. Nuclear Regulatory Commission

\section{Comment: 23}

The topographic map shows that there are five trench drains; two in the energy dissipation area (EDA) of the drainage ditch and three at the toe of the slope of the disposal cell (Also see Section 3.7.1). The NRC is aware of only one trench drain at the EDA (PID 13-S-30) as is shown in Drawing LKV-DS-10-1313 of the Final Completion Report (FCR). Please discuss the purpose of the other four drains and revise either the LTSP or the FCR as appropriate.

\section{SECTION 2}

Response: Page NA

By: J. Crain

Date: Nov. 23, 1993

Sheet flow from the disposal cell's south-facing sideslope and concentrated flow in the ditch overtopped the existing toe apron and ditch outlet structure during and after periods of intense rainfall. Consequently, headcutting occurred at the toe apron and ditch outlet. The additional drains were added 2 years after the completion of the disposal cell (a Project interface document was not issued) to eliminate the problem of gullies forming at the toe of the sideslope and at the ditch outlet. Details of the trench drain(s) are presented on as-built drawings LKV-DS-10-1321 and LKVDS-10-1325.

Plans for Implementation: None. 


\section{SECTION 1}

Site: Lakeview, Oregon

Date: Feb. 12, 1993

Document: Long-Term Surveillance Plan

Reviewer: U.S. Nuclear Regulatory Commission

Comment: 24

Note 3 on the topographic map states that the project area is defined by a dashed line. However, since roads and other features are shown by dashed lines, it is not clear where the project area is located. It is suggested that a thicker dashed line or other symbol be used to distinguish the project area from other dashed lines.

\section{SECTION 2}

Response: Page Plate 2

By: L. Crain

Date: Nov, 23, 1993

Concur.

Plans for Implementation: A thicker dashed line now defines the project area. 


\section{SECTION 1}

Site: Lakeview, Oregon

Date: Feb. 12,1993

Document: Long-Term Surveillance Plan

Reviewer: U.S. Nuclear Regulatory Commission

Comment: 25

Note 4 on the topographic map states that the site boundary is defined by a solid line. However, since the map has many solid lines, it is not clear where the site boundary is located. It is suggested that a thicker solid line or other symbol be used to distinguish the site boundary from other solid lines.

\section{SECTION 2}

Response: Page Plate 2 By: J.Crain Date: Nov. 23, 1993

The solid lines were intended to define areas covered in oblique (aerial) photographs. The area shown on the map is too small to include the complete areas covered by oblique photographs; hence the solid lines were omitted from the drawing.

Plans for Implementation: Note 4 has been deleted from the map. 


\section{SECTION 1}

Site: Lakeview, Oregon

Date: Feb. 12, 1993

Document: Long-Term Surveillance Plan

Reviewer: U.S. Nuclear Regulatory Commission

Comment: $\underline{26}$

The Boundary Marker shown on the topographic map at Northing 24,723.00, Easting 17,778.00, is shown incorrectly as BM-1. This should be corrected to BM-2.

\section{SECTION 2}

Response: Page Plate 2

By: L. Crain

Date: Nov, 23, 1993

Concur.

Plans for Implementation: The map has been corrected. 


\section{SECTION 1}

Site: Lakeview, Oregon

Date: Feb. 12,1993

Document: Long-Term Surveillance Plan

Reviewer: U.S. Nuclear Regulatery Commission

Comment: 27

The symbol on the topographic map for Boundary Marker BM-1 at Northing 26,667.00, Easting 17.778.00, is shown incorrectly as a small square instead of a small circle with a cross through it. Please correct.

\section{SECTION 2}

Response: Page Plate 2

By: J. Crain

Date: Nov. 23, 1993

Concur.

Plans for Implementation: The small square is now used consistently for boundary markers and is so noted in the legend. 


\section{SECTION 1}

Site: Lakeview, Oregon Date: Feb. 12, 1993

Document: Long-Term Surveillance Plan

Reviewer: U.S. Nuclear Regulatory Commission

Comment: $\underline{28}$

In the topographic map, the symbols in the Legend for "Trail or Cleared Line" and "Spot Elevation" are not shown.

\section{SECTION 2}

Response: Page Plate 2

Concur.

Plans for Implementation: Symbols have been added to the legend. 


\section{SECTION 1}

Site: Lakeview, Oregon

Date: Feb. 12,1993

Document: Long-Term Surveillance Plan

Reviewer: U.S. Nuclear Regulatory Commission

Comment: 29

The location of monuments, markers, and settlement plates shown in the topographic map are not the same as they are in the As-Built drawings in the Final Completion Report. Please make the appropriate corrections.

\section{SECTION 2}

Response: Page Plate 2

By: J.Crain

Date: Nov. 23, 1993

Locations of monuments, markers, and settlement plates on the final topographic map were taken from as-built drawing LKV-DS-10-1325. The reviewer needs to specify the discrepancies as there are no obvious differences between the two drawings.

Plans for Implementation: None. 


\section{SECTION 1}

Site: Lakeview, Oregon

Date: Dec. 29, 1992

Document: Long-Term Surveillance Plan

Reviewer: Grand Junction Projects Office

Comment: Page 2-9

" Crest/Top Slope" bullet

What sort of calculation would be performed?

\section{SECTION 2}

Response: Page 2-9

By: J. Crain

Date: Nov, 23, 1993

Comment acknowledged.

Plans for Implementation: The following sentence has been added to the crest/topslope paragraph:

"Temple's method for determining the stability of grass-lined channels (and slopes) would be used to assess the stability of a vegetated topslope area that was damaged or destroyed by disease or fire (Temple et al., 1987)." 


\section{SECTION 1}

Site: Lakeview, Oregon

Date: Dec. 29, 1992

Document: Long-Term Surveillance Plan

Reviewer: Grand Junction Projects Office

Comment: Page 3-1, Section 3.1, Paragraph 3

Attachment 6 is missing. Attachment 6 is referenced in Sections 3.2, 3.4, and 3.5.

\section{SECTION 2}

Response: Page 3-1, Attachment 3

By: M. Day

Date: Nov. 23, 1993

Concur.

Plans for Implementation: The parenthetical reference in Section 3.1 has been deleted. Appropriate changes have been made throughout the document. Attachment 3 replaces Attachment 6. Attachment 3 is the Lakeview Permanent Site File Index, not the contents of the file. The index has been added as Attachment 3. 


\section{SECTION 1}

Site: Lakeview, Oregon

Date: Dec. 29, 1992

Document: Leng-Term Surveillance Plan

Reviewer: Grand Junction Projects Office

Comment: Page 6-2, Section 6.3, 4th bullet

Page 6-2, Section 6.3, 4th bullet this page: notification of "adjacent land owners."

The GJPO thinks adjacent land owners should be identified (name, address) in the LTSP.

\section{SECTION 2}

Response: Page 6-2 By: C.Silva

Date: Nov, 23, 1993

Concur.

Plans for Implementation: The following sentences have been added to the fourth bullet:

"Names and addresses of adjacent land owners are provided in the Lakeview permanent site file at GJPO. An index of the Lakeview permanent site file is provided in Attachment 3."

The GJPO will be responsible for keeping this information updated in the Lakeview permanent site file and in the final Lakeview LTSP index, after the site is transferred to the GJPO. 


\section{SECTION 1}

Site: Lakeview, Oregon

Date: Dec, 29, 1992

Document: Leng-Term Surveillance Plan

Reviewer: Grand Junction Projects Office

Comment: Page 6-3, 2nd bullet

Reword: "If significant disturbance or damage is detected, maintenance or repair will be made."

\section{SECTION 2}

Response: Page 6-3 By: M. Gawthrop

Date: Nov, 23, 1993

Comment acknowledged.

Plans for Implementation: The requested change has been made. 


\section{SECTION 1}

Site: Lakeview, Oregen

Date: Dec. 29, 1992

Document: Leng-Term Surveillance Plan

Reviewer: Grand Junction Projects Office

Comment: Page 6-3, 4th bulles

No site perimeter road was identified during the V\&O inspection of this site, nor does such a road appear on the drawing for the LTSP. Please clarify.

\section{SECTION 2}

Response: Pago 6-3

By: L. Crain

Date: Nov, 23, 1993

No perimeter road exists at the Lakeview (Collins Ranch) disposal site.

Plans for Implementation: The bulleted item has been deleted. 


\section{SECTION 1}

Site: Lakeview, Oregen

Document: Long-Term Surveillance Plan

Date: Dec. 29, 1992

Reviewer: Grand Junction Projects Office

Comment: Page 6-3, last paragraph

Change sentence to read: "Site features or conditions . . . will be photographed if appropriate." This will give inspectors the option to omit the photograph in some instances and state there has been no change from the previous inspection.

\section{SECTION 2}

Response: Page N/A

Only those features or conditions requiring a written explanation or description by the inspectors will need to be photographed. The intent of the comment was understood; however, no text change has been made.

Plans for Implementation: None. 
i!
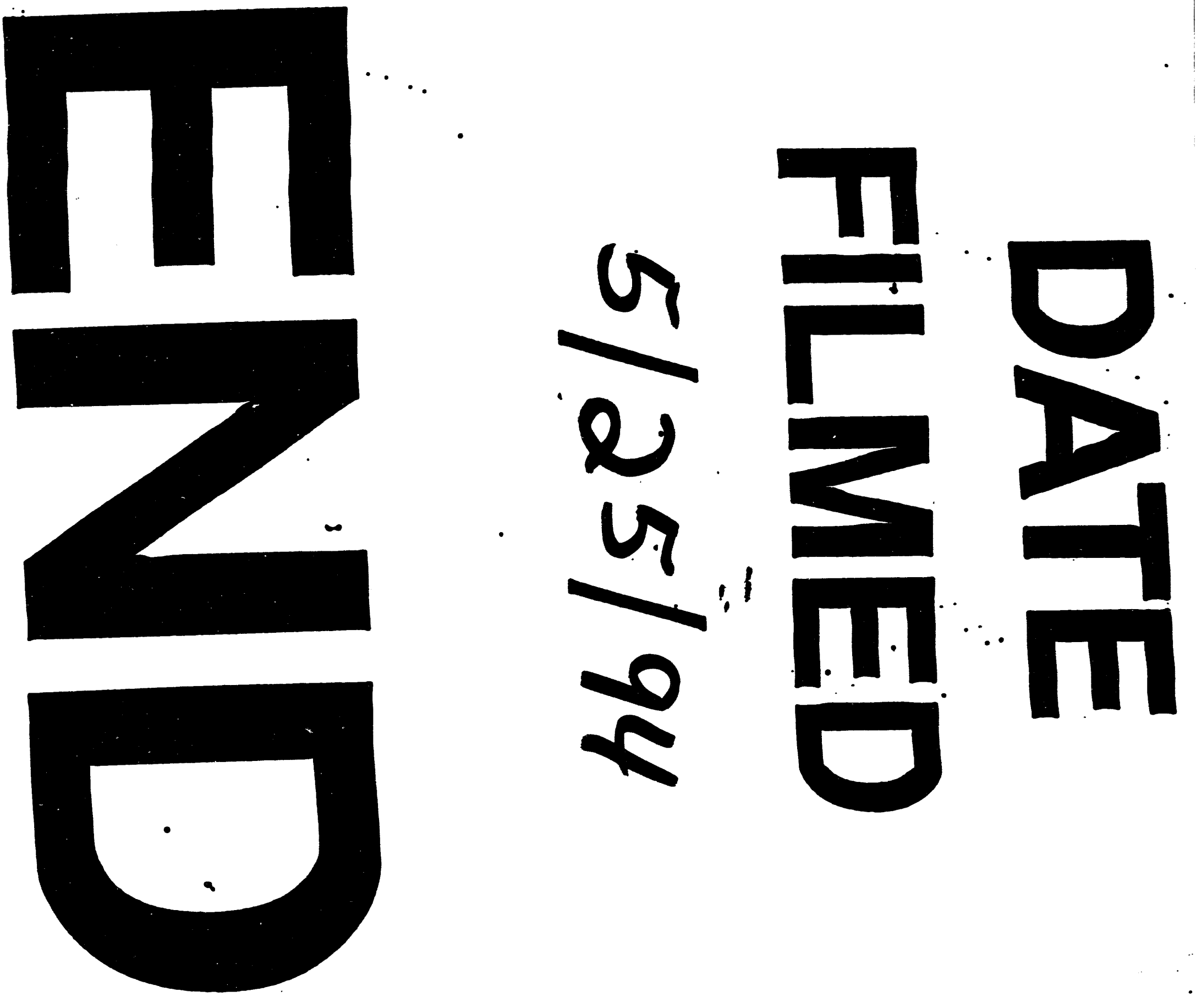
